\title{
Operational Invariants and Instrumentalization of Artefact Study and Research Path for High School: A Case Study
}

\author{
Verónica Parra iDa \\ María Rita Otero $(D)$ \\ ${ }^{a}$ Universidad Nacional del Centro de la Provincia de Buenos Aires (UNCPBA), Núcleo de Investigación en \\ Educación en Ciencia y Tecnología (NIECyT), Consejo Nacional de Investigaciones Científicas y Técnicas \\ (CONICET), Tandil, Argentina.
}

Received for publication 5 Oct. 2020. Accepted after review 6 Aug. 2021 Designated editor: Claudia Lisete Oliveira Groenwald

\begin{abstract}
Background: one of the challenges of a teacher's activity is to use, assimilate and adapt the available resources with which the functional teaching of a mathematical knowledge will be created. Objective: we are interested in the instrumentalization process from which a mathematics teacher uses and assimilates a new artefact: a study and research path (SRP) on the operation of parabolic antennas. Design: This is a case study. Setting and participants: an experienced teacher and a group of students of a French high school (aged 15-16). Data collection and analysis: SRP formulations, registers and transcripts of two interviews carried out with the teacher before and after the implementation of the SRP, and video recordings of the development of eight class sessions. Results: based on the instrumental approach and Vernaug's definition of operational invariant (OI), we identify and classify into four types the OIs that guide the teachers' mathematical and didactic activity, whose goal is to get the SRP device to work in a mathematics course: linked to the study aids, the mathematical knowledge (explained in the official programme), the time (controlled by the teacher), and the teacher. Conclusions: The OIs are not the absolute 'the situation', 'the institution', the accreditation', 'the qualification', etc. They are combined so that the teacher uses the OIs associated with a classical way of teaching. The instrumentalization process produces an instrument that moves away from the initial SRP artefact.
\end{abstract}

Keywords: Operational invariants; Study and research path.

$\overline{\text { Corresponding author: Verónica Parra. Email: vparra@niecyt.exa.unicen.edu.ar }}$ 


\section{Invariantes Operatorios e Instrumentalización del Artefacto Recorrido de Estudio e Investigación para la Escuela Secundaria: un Estudio de Caso}

\section{RESUMEN}

Contexto: uno de los desafíos de la actividad de un profesor consiste en utilizar, asimilar y adaptar los recursos que tiene disponibles y con los cuales gestará la enseñanza funcional de un saber matemático. Objetivo: nos interesamos en el proceso de instrumentalización a partir del cual una profesora de matemática utiliza y asimila un nuevo artefacto: un recorrido de estudio e investigación (REI) sobre el funcionamiento de las antenas parabólicas. Diseño: Se trata de un estudio de caso. Ambiente y participantes: una profesora experimentada y un grupo de estudiantes de la escuela secundaria francesa (estudiantes de 15-16 años). Recolección y análisis de datos: formulaciones del REI, registros y trascripciones de dos entrevistas efectuadas a la profesora previo y posterior, respectivamente, a la implementación del REI, registro en vídeo del desarrollo de ocho sesiones de clases. Resultados: a partir del enfoque instrumental y de la definición de invariante operatorio (IO) de Vergnaud, identificamos y clasificamos en cuatro tipos los IOs que guían la actividad matemática y didáctica de la profesora, cuya meta es lograr que el dispositivo REI funcione en un curso de matemática: vinculados a las ayudas al estudio, al conocimiento matemático (explicitado en el programa oficial), al tiempo (controlado por parte del profesor) y al profesor. Conclusiones: Los IOs no son absolutos. La situación, la institución, la acreditación, la calificación, etc. se combinan para que la profesora utilice IOs asociados a una enseñanza clásica. El proceso de instrumentalización produce un instrumento que se aleja del artefacto REI inicial.

Palabras clave: invariantes operatorios; recorrido de estudio e investigación.

\section{Invariantes Operatórios e Instrumentalização do Artefato Percurso de Estudo e Pesquisa para o Ensino Médio: um Estudo de Caso}

\section{RESUMO}

Contexto: um dos desafios da atividade de um professor consiste em utilizar, assimilar e adaptar os recursos de que dispõe e com os quais irá desenvolver o ensino funcional de conhecimentos matemáticos. Objetivo: interessa-nos o processo de instrumentalização a partir do qual um professor de matemática usa e assimila um novo artefato: um percurso de estudo e pesquisa (PEP) sobre o funcionamento de antenas parabólicas. Design: Este é um estudo de caso. Cenário e participantes: uma professora experiente e um grupo de alunos do ensino médio de uma escola francesa (alunos de 15 a 16 anos). Coleta e análise de dados: formulações do PEP, registros e transcrições de duas entrevistas com a professora antes e após a implantação do PEP, respectivamente, gravação em vídeo do desenvolvimento de oito aulas. Resultados: com base na abordagem instrumental e na definição de invariante operatório (IO) de Vergnaud, identificamos e classificamos os IOs em quatro tipos que norteiam a 
atividade matemática e didática do professor, cujo objetivo é fazer o dispositivo PEP funcionar em um curso de matemática, vinculados à ajuda ao estudo, ao conhecimento matemático (especificados no programa oficial), ao tempo (controlado pelo professor) e ao professor. Conclusões: os IOs não são absolutos. A situação, a instituição, o credenciamento, a qualificação etc. são combinados para que o professor use IOs associados a um ensino clássico. O processo de instrumentalização produz um instrumento que se distancia do artefato PEP inicial.

Palavras-chave: invariantes operatórios; percurso de estudo e pesquisa.

\section{INTRODUCTION}

Knowing how to act and say something in a situation is a highly complex and interrelated aspect of building knowledge. The theory of the conceptual fields (Vergnaud, 1990, 1998, 2013) acknowledges two forms of knowledge in permanent, not opposing, interaction, the operational form and the predicative form, and affirms that knowledge cannot be reduced to one form or the other.

The instrumental approach was proposed by Pierre Rabardel (1995) from the activity theory (Vygotsky, 1978) of the theory of the conceptual fields (TCF) and is introduced and developed in the field of professional didactics and ergonomics. When a subject is in a labour-type situation that demands an activity aimed at a goal, he/she needs to interact with artefacts, understood as devices generated by human activity, whether of didactic type, machines, etc. These interactions cause the subject to develop an instrument composed of the artefact plus a usage scheme (Vergnaud, 1998, 2013) of that artefact. In this way, the instrument obtained as a product of those interactions is a new instrument that may or may not coincide with the one initially manipulated by the subject.

An instrument is not developed at once but through a process called instrumental genesis, which comprises two interrelated processes. The first, instrumentalization, is the process according to which the subject assimilates the artefact based on the schemes they already have. In other words, here, the subject who appropriates the artefact prevails, based on what they previously know. For example, different teachers with the same didactic device, the study and research path (SRP) (Chevallard, 2004), and similar goals can generate instrumentalizations that, in turn, produce different instruments (SRP). At the same time, another process, called instrumentation, occurs, with the predominance of the characteristics and peculiarities of the artefact. Consequently, the subject must adapt their schemes, i.e., they must modify them. These are dialectical and never-ending processes. No matter how expert a 
professional is in using a tool, it can always be enhanced, developing new aspects. This is particularly true in a teacher's professional life. Consequently, to identify instruments and instrumentations, one must be able to describe the modifications the schemes undergo, and the operational invariants (OI) are the methodologically most economical way to access Vergnaud's scheme (1998, 2013).

In this work, we are interested in the use and assimilation process of a new didactic artefact implemented by a mathematics teacher who intended to develop an SRP on the operation of parabolic antennas (Bellenué et al., 2014). In line with Vergnaud $(1998,2013)$, we focused on identifying and detailing the OIs that guide this teacher's mathematical and didactic activity, whose goal is to make the SRP work in a French high school mathematics course (students aged 15-16). In Gueudet, Lebaud, Otero, and Parra (2018), we published another aspect of this work: the teacher's documentary work when implementing the SRP; here, we focused on the specific interactions between the teacher and the resources (resource system) when implementing the artefact. Although there is some reference to the operational invariants, we did not detail how they were inferred or how the typology presented was generated.

\section{THEORETICAL FRAMEWORK}

The theoretical framework is the theory of the conceptual fields (TCF), focusing on operational invariants. The instrumental approach and the anthropological theory of the didactic (ATD) are related to the consideration of a particular type of "artefact" (SRP) and the process of instrumentalization carried out with it. TCF is the main reference because we are interested in the level of the subject who learns, not as a "person" in particular but as an epistemic and social subject, who assimilates an artefact to their schemes of action. For this level of analysis, the TCF is more functional than the ATD, where the personal level is more blurred and requires adopting questionable constructs such as the so-called "personal praxeologies" which, in our opinion, lack support, since the praxeological level is social and, for example, does not allow to explain the teacher's assimilation of the SRP artefact.

\section{Operational and predicative forms of knowledge}

Vergnaud (1990, 1998, 2007, 2013) proposes two forms of knowledge in permanent, not opposing, interaction: the operational and the predicative form. The operational form is the one that allows the subject to act with a 
specific event in a situation. According to Vergnaud (2013), it is very positive that the operational form of knowledge is considered relevant (Otero, 2019). However, this does not lessen the importance of the predicative form, whose function ranges from identifying the objects of the world and recognising them to stating what we do, generating texts and books on how specific things are done. For teaching and learning, it is essential to take into account that knowledge begins long before we are able to put it into words. The TCF is a pragmatic theory of the conceptualisation of the real that offers theoretical instruments to analyse the activity of the subject in the situation, the form of the activity, what is preserved and what changes, the schemes that the subject puts into play, and the pragmatic and epistemic conditions that produce the learning, the conceptualisation and the development in a specific domain.

\section{Situations, schemes, activity, and operational invariants}

To study the learning of a specific domain, we must precisely establish a relationship with that portion of the real that manifests itself in a situation, in "une tâche" (task). The situation, says Vergnaud (1998, p.8), has the character of a task. Any complex situation can be analysed as a combination of tasks about which it is valuable to know nature and obstacles. Indeed, a situation represents a whole class of situations with well-defined epistemological specificities. The subjects adapt to the situations they face, but, in fact, it is the schemes they use in the situation that are modified during the adaptation. Thus, a class of situations summons specific schemes that develop by virtue of the type of situation.

Among the four definitions of scheme proposed by Vergnaud (1990, $2007,2013)$, we selected the following. A scheme is necessarily composed of four classes of components: a goal or several sub-goals and anticipations, the rules of action, capture, and control of information, operational invariants (concepts-in-action and theorems-in-action) and possible inferences. A concept-in-action is not a concept, nor is a theorem-in-action a theorem, strictu sensu. In science, concepts and theorems are explicit, and their relevance and truth can be discussed. This is not necessarily the case for operational invariants. Explicit concepts and theorems form only the visible part of the iceberg of conceptualisation; but without the hidden part formed by the operational invariants, this visible part would be nothing. These operational invariants (concepts-in-action and theorems-in-action) are, in particular, the implicit (or explicit) conceptual basis of the schemes because they allow selecting relevant 
information and, from this information and the goal to be achieved, inferring the most appropriate rules of action to address a situation (Vergnaud, 1990).

In summary, the concept of scheme is relevant to gestures, reasoning, technical and scientific operations, social and linguistic interactions, affectivity, and emotions. All activity records are present at work, in continuing education situations, and school initial education.

\section{Instrumental approach}

The instrumental approach (Rabardel, 1995, 2002; Bueno-Ravel \& Gueudet, 2013; Gueudet \& Trouche, 2008; Trouche, 2016, Trouche, Gueudet, Pepin, \& Aldon, 2020) has been introduced in the field of professional didactics (PD), within the cognitive ergonomics by Rabardel (2002), based on the theory of activity (Vygotsky, 1978) and the TCF. This approach proposes that when a subject is in a situation that demands an activity aimed at a goal, he/she interacts with artefacts (devices generated by human activity, SRP, machines, artefacts). These types of interactions cause the subject to develop an instrument that comprises the artefact and a usage scheme (Vergnaud, 1998, 2013) of that artefact.

The process of developing an instrument is called instrumental genesis. Instrumental genesis comprises two related processes. The first, instrumentalization, refers to how the subject's schemes affect how the artefact is appropriated - assimilated. For example, different teachers with the same SRP and similar goals can generate instrumentalizations and their product: instruments, different. On the other hand, the characteristics of the artefact affect the schemes the subject developed in the course of a process called instrumentation. The activity with an artefact is described by the evolution of the subject's schemes (Rabardel, 2002). Consequently, to identify instruments and instrumentations, it is crucial to be able to describe the changes the schemes undergo, and according to Vergnaud (1998), this is done from the analysis of the operational invariants.

\section{Study and research paths (SRP)}

The anthropological theory of the didactic (ATD) defines the SRP as didactic devices aimed at proposing the school study in terms of questions, called generative questions. The SRP is a particular type of artefact, not a routine math exercise or an appliance. The SRP artefact has very different 
manipulation characteristics from any other. For example, starting and developing the study process from questions in the strong sense, i.e., a question the answer of which is not the immediate elaboration of a manuscript but the result of a sustained process over time, through gestures analogous to a researcher's. There would not be a genuine SRP if at least a subset of those gestures we mention below were not identified. A detailed description can be found in Parra and Otero (2018): formulating questions and building answers, studying and researching, exploring disciplines and delimiting areas, entering and leaving the topics, studying what is relevant, what is necessary, building the medium of study, cooperating and collaborating in the construction of answers, deconstructing and rewriting existing answers, disseminating and receiving them, and analysing and synthesising.

At the beginning of an SRP, there is a preliminary analysis of the potential of the question addressed. This initial openness is necessary so that the generative question is more important than the answer that must be provided and does not become, as it happens most of the time, a pretext for constructing the knowledge proposed in official programmes. And this is another of the characteristics that make the SRP an artifact that differs from an activity, problem, or "traditional" exercise.

\section{RESEARCH METHODOLOGY}

In France, there are the so-called Institutes of Research in Mathematics Education (IREM), which embrace secondary school teachers interested in mathematics didactics and researchers in the area.

The IREM of Poitiers developed a book (Bellenoué et al. 2014) for teachers of the first grade of the French high school (students aged 15-16) guided by Chevallard's analysis (2004) of the functionality of mathematics in educational systems. The book poses three questions: $\mathrm{Q}_{0}$ : How does a satellite antenna work? $\mathrm{Q}_{1}$ : How do two fast circulation routes connect? And $\mathrm{Q}_{2}$ : How to optimise a quantity? In our case, the SRP corresponds to question $\mathrm{Q}_{0}$.

The implementation was carried out in a French high school mathematics module (students aged 15-16) during eight class sessions in the 2016/2017 school year. This work does not focus on describing the implementation of the SRP in the classroom but on using those records to determine the actions developed that align with the operational invariants (OI) inferred from the interviews. 


\section{The case focused on the teacher ${ }^{1}$}

When this research took place, the teacher under analysis had worked at the high school level for more than 35 years as a team with the other mathematics teachers in the institution. At the beginning of every academic year, all mathematics teachers jointly design the annual planning for their courses, analysing the continuities between each school level and each programme unit. This planning contains the exact duration for each unit, the notions to be addressed, and the dates of the unit assessments, which other mathematics teachers correct, i.e., a teacher does not correct his/her students' written assessments but another teachers'. Under these conditions, the teacher decided to implement the SRP, knowing that this would change all aspects of planning.

The teacher has access to the paper resource (Bellenoué et al. 2014) describing the path and a possible way to implement it in class. They also have the digital material linked to the book available, with restricted access, on the IREM Poitiers website.

The IREM has a computer and a projector permanently installed in each classroom, a blackboard, an internet connection and a good library, which are essential for developing an SRP. Even so, the teacher is involuntarily restricted. Some boundaries are linked to the little documentation about how to develop an SRP in a regular classroom, with the spaces and times delimited in advance and with the resources available. Both the conditions and the restrictions influence the area where the teacher develops her operational invariants.

\section{Registers and data collection}

Regarding the design of the SRP, we have the paper and digital versions of the book and the digital material available on the website.

About the SRP, we have the audio recordings of the two interviews with the teacher, one before the implementation (interview 1), another after the implementation (interview 2), and their transcripts. From those registers, we inferred the OIs, i.e., the teacher's utterances that we believe correspond to the OI. We have the video recordings of the development of the SRP in the

\footnotetext{
${ }^{1}$ The informed consent form (ICF) has not been necessary, nor has the request for an ethical assessment since the teacher is not considered as a "person" but as an epistemic and social subject. Moreover, the teacher was aware of the data destination and analysis. We exempt the Acta Scientiae from any consequence derived thereof, including full assistance and eventual compensation for any damage that results to any of the research participants, in accordance with Council Resolution No. 510, of April 7, 2016, of the National Health Council of Brazil.
} 
classroom and field notes. Those registers were used to support the previously constructed OIs. We also have the digital version of the material the teacher proposed to the students and the resources she used to select the additional activities posed and used in classes. Those registers help identify and describe the changes the teacher introduced to the SRP artefact and, just like the classroom registers, support the OIs constructed from the interviews.

\section{Data analysis}

Each interview was transcribed and segmented into utterance shifts. The statements that we consider linked to possible operational invariants (OI) were marked in each transcript. For each transcript, the time (in minutes) in which that proposition was identified, the line (s) of the transcript corresponding to that segment of the interview and the formulation of the possible OI were registered.

After listing the OIs, we built Table 1 (Annex 1), which contemplates a classification of the OIs. The first column of this table corresponds to the type of OI (which we detail in the section related to results and discussions); the second column contains each OI; the third column, the lines of the transcript, showing a 1 (L1) or 2 (L2) if it is a line of interview 1 or a line of interview 2; the fourth column contains the changes and the fifth column, the class sessions. The objective of the latest two additions is to identify the teacher's changes that would underlie those OIs and the consequences of such modifications during the class sessions. Regarding the classes, we placed in the table the session number and the action the teacher developed based on those changes. With this, we intend to show signs of these OIs not only from the interviews (from which we inferred them) but also from the activities and other actions reflected in the modifications and development of the SRP in the classroom.

\section{Table 1}

Classification of OIs

\begin{tabular}{|c|c|c|c|c|}
\hline $\begin{array}{c}\text { Type of } \\
\text { OIi }\end{array}$ & OIij & Lines (L1; L2) & Changes & $\begin{array}{c}\text { Class } \\
\text { sessions }\end{array}$ \\
\hline
\end{tabular}




\section{DESCRIPTION OF THE SRP}

Question $\mathrm{Q}_{0}$ : How does a satellite antenna work? is directed to the construction of tangents to a curve from analytical geometry. The objective is to introduce the calculation of growth rates leading to the notion of derivative. Thus, elaborating a response to Q0 allows rediscovering properties of synthetic and analytical geometry, of geometrical and wave optics. Studying the reflection of electromagnetic waves on different surfaces is necessary to explain the operation of various light transmission and reception equipment, essential for current communications and other uses in architecture, cars, solar energy, etc. Bellenoué et al. (2014, p.47) explain that the main mathematical knowhows addressed in this first path are those presented in Table 2:

\section{Table 2}

Main mathematical know-hows

$\begin{aligned} & \text { Equation of the circumference from its characteristic } \\ & \text { elements. }\end{aligned}$
Determination of $\begin{aligned} & \text { Equation of a straight line. } \\ & \text { Relative position of two lines. } \\ & \text { Canonical form of a second degree trinomial. }\end{aligned}$
Resolution of a quadratic equation.
Algebraic determination of the coordinates of the points of intersection of
two curves.
Proof that a straight line is tangent to: a circle, a parabola, a hyperbola.

The book proposes the historical analysis of tangents to a curve and the development of the works linked to it. It also includes optics questions that address the problem of reflection on different surfaces, which lead to the study of the conic sections and tangents to those curves. The book shows experiments about the reflection of light on several surfaces, which leads us to consider how this phenomenon occurs for different mirrors: cylindrical, parabolic or hyperbolic.

The book proposes two investigations: one on parabolic antennas and the other on reflection in a flat mirror. The objectives of these investigations 
are: to establish that reflection is specular and depends on the shape of the reflection surface (flat, circular, parabolic, etc.) and to insist on the notions studied in the previous module of physics on Descartes' law of reflection, the notion of plane of incidence, and the law of angles on a flat surface. Then, it proposes a study called "Cylindrical mirror" (labelled "Study 1"), which is composed of a set of three activities or "Parts": Part 1 titled "Construction with ruler and compass"; Part 2, "Reflected ray" and Part 3, titled "Unreflect rays." Subsequently, it proposes a study called "Parabolic mirror" (labelled "Study 2") and which leads to formulating the notion of a tangent to a curve. After that, the book proposes an exercise to finish the SRP. This exercise shows the convergence of the reflected rays towards the parabola focus from the incident rays parallel to its axis. Finally, three possible types of written assessment are proposed.

The objective of "Part 1" (Figure 1) is, first, to make a construction with a ruler and compass, and second, with the GeoGebra software.

\section{Figure 1}

Study 1, Part 1 (Bellenoué et al. 2014, p.50)

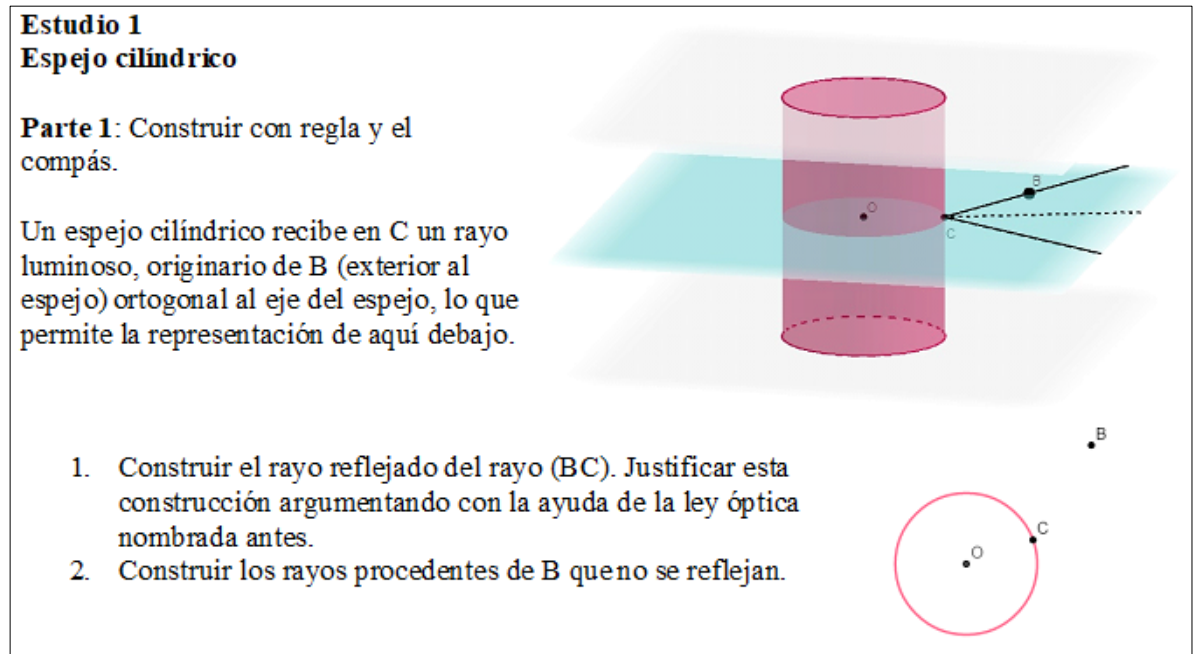

The techniques proposed to solve this activity are presented in Table 3: 


\section{Table 3}

\section{Main techniques proposed}

Plot a semi-straight line symmetrical to the incident beam in relation to the radius $(\mathrm{OC})$.

Perform successive zooms around $\mathrm{C}$ to show that it can be considered infinitely small segments.

Make a construction schedule.

The objective of "Part 2 of Study 1" (Figure 2) is to build the reflected ray with GeoGebra and then find the equations obtained in the software by hand.

\section{Figure 2}

Study 1, Part 2 (Ibid., p.51)

Parte 2: Rayo reflejado
Consideramos el círculo $\mathrm{C}_{1}$ de centro $\mathrm{O}$, de radio 6 y los puntos
$\mathrm{B}(6 ; 10)$ y $\mathrm{C}(4,8 ; 3,6)$.
1. Construir el rayo reflejado del rayo (BC) con GeoGebra
(verificaremos que $\mathrm{C}$ pertenece al círculo $\mathrm{C}_{1}$ ).
2. Encontrar el resultado dado por GeoGebra para la
ecuación del rayo reflejado.

The objective is to analyse and complete the knowledge for a first study in an analytical geometry class on the notions detailed in Table 4:

\section{Table 4}

Complementary notions

Cartesian equations of lines and the reduced equations. 
Distinction between parallel and non-parallel lines to the ordinate axis.

Directing coefficient $\left(y_{B}-y_{A}\right) /\left(x_{B}-x_{A}\right)$ of the line that passes through $A$ with $B \operatorname{con} x_{A} \neq x_{B}$.

Reduced equation of the line with directing coefficient $m$ that passes through a point A.

Conditions of parallelism and perpendicularity of two lines knowing the reduced equations.

Coordinates of the midpoint of a segment.

The proposition is to distinguish three types of activities: to move from Cartesian equations to reduced and inverse equations; to construct the equations of lines from various data; to verify the parallelism and perpendicularity of two lines.

\section{Figure 3}

Study 1, Part 3 (Ibid., p.52)

Parte 3: Rayos que no se reflejan.

Sea el círculo $\mathrm{C}_{1}$ de centro $\mathrm{O}$ y de radio 6 y $\mathrm{B}_{1}(6 ; 10)$.

1. Construir con GeoGebra@ los rayos procedentes de $B_{1}$ que no se reflejan sobre el espejo. Justificar todos los resultados que aparezcan en la vista algebraica.

2. Hacer lo mismo para los rayos procedentes de $\mathrm{B}_{2}(18 ; 18)$.

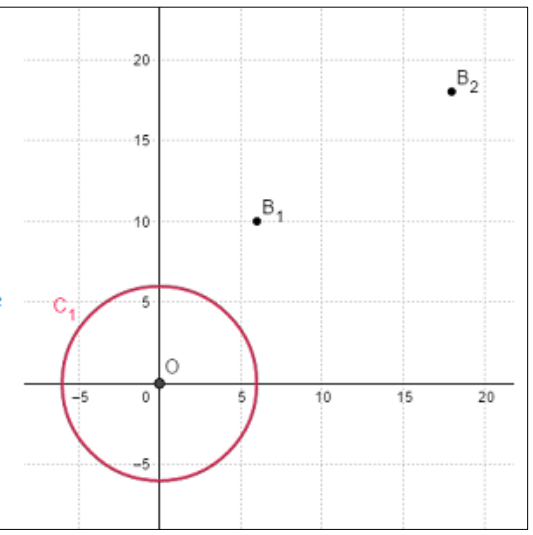

"Part 3 of Study 1" (Figure 3) proposes to build, using GeoGebra, the rays that are not reflected. This part aims to recognise the equations of tangent lines of the type $x=a$ and introduce the circumference equations with the teacher's help based on the formula of the distance between two points (in an orthogonal system). In this way, onde should carry out a first study in the 
classroom on the circumference equations: developed form, canonical form and find the second-degree equations in their canonical form.

In Part 3, they propose to distinguish three types of activities: to determine the equation of a given circumference of a given centre and radius, to determine the equation of a circumference with a given diameter, and to determine the set of points that verify an equation of the form $x^{2}+y^{2}+a x+$ $b y+c=0$. Study 2 (Figure 4) aims to define the tangent to a curve at a point, find a formula for the tangent, and verify that this line is the tangent.

\section{Figure 4}

Study 2 (Ibid., p.54)

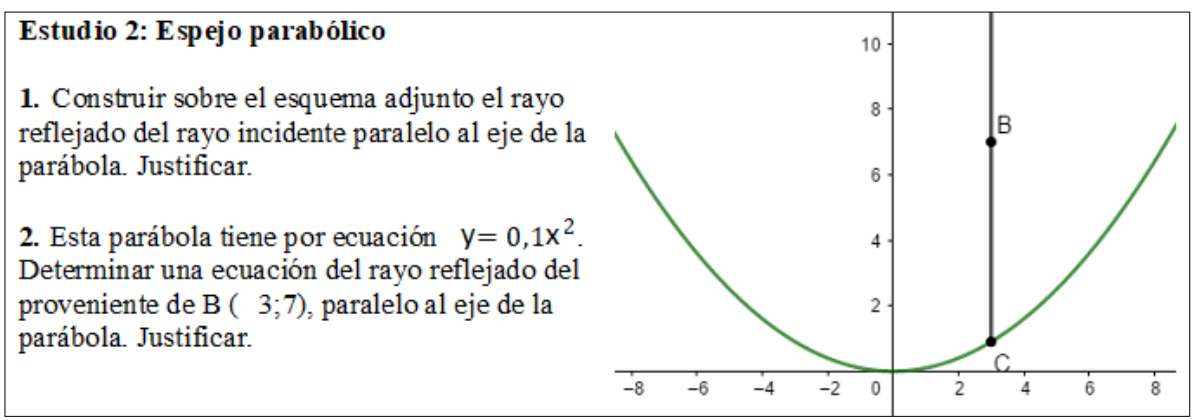

Table 5:

The book assumes four possible ways to plot the tangent, mentioned in

Then, the antenna operation is explained from the convergence towards the parabola focus by the incident rays parallel to the axis. The proposal is to complete this study by demonstrating that the signals emitted simultaneously reach the focus. The book also proposes a set of exercises, available in a section of the book called "Exercises databank" for each research and study. Exercises on equations (of lines, parabolas, circumference), tangents to a circle, tangents to conics - including one about a tangent line to a hyperbola at a point (Figure 5) - and historical documents are covered here.

\section{Table 5}

Possible ways to plot the tangent 


\begin{tabular}{ll}
\hline 1 & By approximation, zooming around the $\mathrm{C}$ point. \\
2 & $\begin{array}{l}\text { Making a circle tangent to the parabola appear at point } \mathrm{C} \text {, the tangent } \\
\text { to the circle in } \mathrm{C} \text { is the tangent to the parabola. }\end{array}$ \\
3 & With the symmetrical derivative. \\
4 & $\begin{array}{l}\text { By a more algorithmic method that allows a formula to be obtained } \\
\text { by pivoting a non-vertical line around } \mathrm{C} \text {, the line should not be cut } \\
\text { the parabola again. }\end{array}$ \\
\hline
\end{tabular}

\section{Figure 5}

Tangent to the hyperbola at a point (Ibid., p.81)

Ejercicio 36. Una construcción geométrica de la tangente en un punto de una hipérbola.
Sea $\mathrm{A}(1 ; 1)$ un puto de la hipérbola $(\mathrm{H})$ de ecuación
$y=\frac{1}{x}$.
La paralela al eje de abscisas que pasan por A corta
al eje de ordenadas en $\mathrm{B}$.
Notamos $\mathrm{B}^{\prime}$ al simétrico del Origen $\mathrm{O}$ con respecto
a B.
1. Determinar las coordenadas de $\mathrm{B}^{\prime}$, luego
una ecuación de la recta (B'A). Demostrar
entonces que (B'A) es la tangente a la
hipérbola en A.
2. Retomar la cuestión 1 en el caso general
con $A\left(a ; \frac{1}{a}\right)$, siendo $a$ un número real no
nulo.

Finally, the book proposes three possible written assessments.

\section{RESULTS AND ANALYSIS}

Firstly, we will detail the OIs inferred from the interviews and the classification into four classes. Then, for each type of OI, we incorporated the changes made by the teacher to the proposed SRP and the actions developed in the classroom that support each of those types of invariants. 


\section{Teacher's OI}

We classified the OIs obtained from Table 1 into four classes:

OIK (knowledge) refers to the notions to be taught and the knowledge studied in the classroom. We listed them in Table 6:

\section{Table 6}

OIs related to knowledge

OIK: Mathematics programme topics need to be addressed
$\mathrm{OIK}_{1}$ : It is necessary to give meaning to what is taught.

$\mathrm{OIK}_{2}$ : The topics of the programme must be addressed.

$\mathrm{OIK}_{3}$ : The SRP allows the contents of the programme to be processed.

$\mathrm{OIK}_{4}$ : It is necessary to prepare the students' encounter with the programme content.

$\mathrm{OIK}_{5}$ : It is necessary to talk about orthogonality before going through the scalar product.

$\mathrm{OIK}_{6}$ : Treat orthogonality linked only to the scalar product is too theoretical and not very helpful.

$\mathrm{OIK}_{7}$ : Perpendicularity is an instrument.

$\mathrm{OIK}_{8}$ : Orthogonality can be treated as perpendicularity.

$\mathrm{OIK}_{9}$ : The SRP allows students to review the subjects they have studied in previous years.

OIT (time) refers to the time of management of the study process, either to allusions about the time that must be spent to solve an activity, develop a question, a validation, etc., and the time actually spent. We listed them in Table 7: 


\section{Table 7}

OIs related to time

$\mathrm{OIT}_{1}$ : It is necessary to control time.

$\mathrm{OIT}_{2}$ : Splitting the class into two groups allows you to control time.

OIT: It is

$\mathrm{OIT}_{3}$ : It is necessary that students carry out the necessary for the investigations outside the classroom not to waste time. teacher to control time.

$\mathrm{OIT}_{4}$ : It is necessary to make up for lost time because of the SRP.

$\mathrm{OIT}_{6}$ : It is necessary that students find good ideas before ten minutes.

$\mathrm{OIT}_{7}$ : The teacher cannot lose control of the class times.

OISA (study aids): here, we consider the propositions that correspond to how to help students. We listed them in Table 8:

\section{Table 8}

OIs relating to study aids

$\mathrm{OISA}_{1}$ : It is necessary for the teacher to give all the tools to the students so that they can calculate.

OISA: It is necessary for the teacher $\mathrm{OISA}_{2}$ : The students do not know to guide the students' work. how to investigate; the teacher must OISA: It is necessary to involve and motivate students (incorporating a context, software, an SRP, etc.). OISA: It is necessary to manage resources well to help the students. help them.

$\mathrm{OISA}_{3}$ : Framed personal works (FPWs) provide research methods to the students.

$\mathrm{OISA}_{4}$ : The students want to do what the teacher indicates.

OISA5: It is necessary to involve and motivate students. 
OISA $_{6}$ : GeoGebra allows students to be motivated.

$\mathrm{OISA}_{7}$ : Verifying GeoGebra outputs from the algebraic view with the calculations is a motivation for the students.

$\mathrm{OISA}_{8}$ : The SRP motivates students.

OISA9: The students are not in a position to calculate alone.

OISA $_{10}$ : GeoGebra reduces students' difficulties because it contains a tool to determine the tangent line.

OISA $_{11}$ : GeoGebra is very intuitive for students.

$\mathrm{OISA}_{12}$ : Students do not find it difficult to use GeoGebra because they have seen the teacher use it.

OISA $_{13}$ : SRPs allow students to tell a story behind the content.

OISA $_{14}$ : The narrative that is behind the problems proposed in an SRP makes students feel that mathematics is more friendly.

OISA $_{15}$ : The SRP allow students to show what mathematics is for.

OISA $_{16}$ : It is necessary to manage resources well to help the students.

OISA $_{17}$ : It is necessary to propose to the students exercises very similar to those proposed in class.

OISA $_{18}$ : It is necessary to propose hyperclassical activities to students. 
OISA $_{19}$ : The final exam must contain both contextualised and technical tasks.

OIP (teacher): in this type of invariant, we consider the propositions that refer to the teacher, to actions that she can and should do. We listed them in Table 9:

\section{Table 9}

OIs related to the teacher

\begin{tabular}{ll}
\hline $\begin{array}{l}\text { OIP: It is } \\
\text { necessary }\end{array}$ & $\mathrm{OIP}_{1}$ : The teacher must mark the topic at the beginning of the \\
that the & $\mathrm{OIP}_{2}$ : The teacher must help students find good ideas. \\
teacher & $\mathrm{OIP}_{3}$ : The teacher should ask students to ask questions. \\
$\begin{array}{l}\text { controls all } \\
\text { the }\end{array}$ & $\mathrm{OIP}_{4}$ : The teacher should not put students at stake. \\
$\begin{array}{l}\text { development } \\
\text { of the study } \\
\text { process }\end{array}$ & $\begin{array}{l}\mathrm{OIP}_{5} \text { : The teacher must avoid situations that students cannot } \\
\text { solve. }\end{array}$
\end{tabular}

\section{Figure 6}

OI according to time and interview

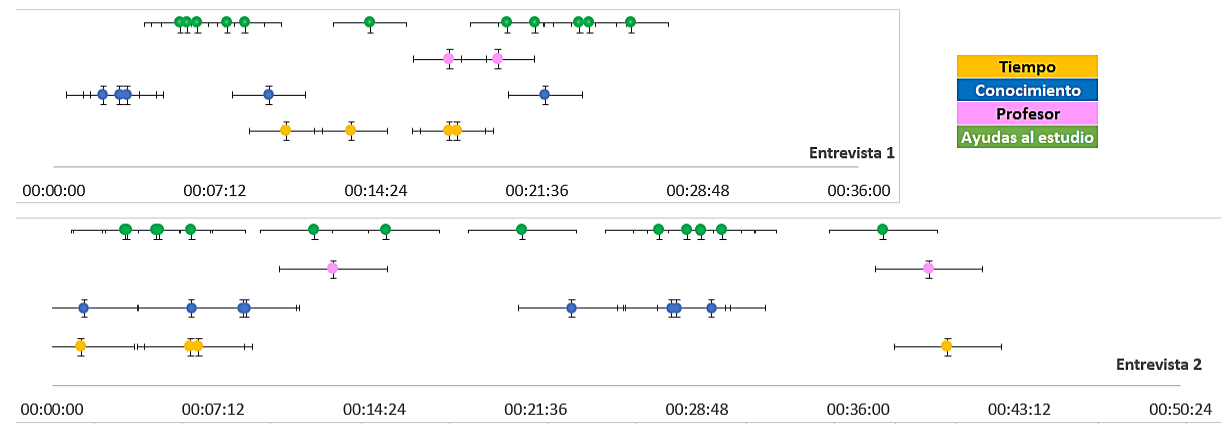

From Table 1, the graph of Figure 6, representing the time in each interview with the four types of OI, was generated. The temporary predominance of invariants linked to study aids is evident. To a lesser extent, 
but also relevant, those related to knowledge and time and finally, those related to the teacher.

\section{Modifications to the SRP and classroom actions: support for each type of OI}

The first change concerned the organisation and management of investigations. The book proposes two investigations: one on parabolic antennas and the other on reflection in a flat mirror. It suggests that students disseminate the result of their searches in front of the whole class. Here, the teacher introduced the first change: she divided the class into two groups and, without showing the slides, asked each to carry out one of the investigations. In groups, the students should investigate the question outside the classroom and deliver the result either printed or by e-mail to the teacher. This change supports the teacher's OIs regarding the time, in particular, its control.

Another change refers to the formulations of the tasks, called "study" in the book. The teacher substantially changed its formulations. For example, in parts two and three of Study 1 (Figure 2 and Figure 3), the teacher deleted point B2 and altered the analysis figure, detailing the representation of the circumferences and lines. She segmented the activity into several subsections: 1/, 2/a/, 2/b/, 2c/, 3/a/ et 3/b/. In Study 2, on parabolic mirrors, the teacher also significantly modified the activity. The book and the teacher intend to introduce the tangent to a curve at a point, determine a formula for the tangent and verify that that line is the tangent. The book proposes four "methods" that can be used to plot the tangent, allowing students to choose and explain that choice. The teacher, on the other hand, did not offer them the possibility of exploring the methods. She presented four graphs, each with the corresponding value of the slope of the tangent line and places spaces with dashed lines for students to complete, and segmented the task in several paragraphs, as in the previous study. That type of changes that generate a "closed" activity affirm the OIs relating to study aids, the OIs relating to the teacher's activity, and the OIs on content. The details in the representations, the statements segmentation, and the lines to be completed indicate that the teacher believes the students must be guided as much as possible when developing the studies. This attitude ensures that she always, or almost always, sticks to the programme.

Another substantial change linked to the design concerns the time (in

minutes) that the teacher placed on the right side of each item, being the maximum time available for the development of each one. In our opinion, this 
modification is another sustenance of the OIs linked to time: the teachers' control of time.

Besides this type of modification, the teacher added a third study, of hyperbolic mirrors. It is exercise 36 of the "exercises databank" of the book. In the teacher's tasks sequence, the hyperbolic mirror occupied an important part, and she proposed to analyse with it the tangent to a hyperbolic curve. Similar to the tasks proposed by the teacher, the activity includes a series of "stages to follow," leaving blanks students should fill in and allowing them some time for its completion. This change is another support of the OIs to time, the study aid, and the teacher.

\section{Table 10}

Teacher actions influenced by her OIs

\section{Actions}

OI on

She maintained the "context" of the mirrors by linking it to the content the programme.

She indicated, highlighted, and controlled the times to be the time used for each activity.

She told students the results they must reach when solving the tasks and tried to incorporate representations with GeoGebra, she herself had made.

study aids

the teacher

She cut out considerably a presentation (slides) proposed by the book. Here, the potential of the SRP in relation to the possible works of study is presented.

The teacher made little use of the section of the book "Exercises databank." From there, she considered the activity on the hyperbolic mirror, which, as we have already described, changed considerably. The teacher used other school books to give examples and propose activities and thus "train" the students in specific types of tasks, for example, on the equations of lines, equations of circumferences, symmetrical points, the passage from one type of equation from a line (circumference) to another type. This selection of activities, extracted from the handbooks commonly used by the teacher and her students, 
is a support of the OIs on the study aids. Thus, exercises with characteristics similar to those that students perform outside the SRP are proposed.

The teacher not only changed the SRP offered by the book but also modified the chapter addressed to the equations of lines and circumferences presented in the curriculum. She claimed to address notions that are not strictly from the 1S programme. She even referred to parallel and perpendicular lines without establishing a link with the scalar product, as proposed in the programme. This change underpins her OIs on content.

In addition to the modifications to the SRP artefact, the teacher performed certain actions during the class sessions that can be considered influenced by her OIs. They are detailed in Table 10.

\section{DISCUSSION}

There is a strong predominance of OIs linked to study aids. The teacher alluded to different forms of what she considered to be "helping" students, from providing answers, solutions, to modifying the "tasks/studies" proposed in the SRP. Such are these modifications that most of them end up generating "traditional/classical" exercises, understanding this type of exercise as those where the solution is almost immediate and does not require complex studies or additional research. This is far from the type of activity proposed in the SRP artefact. OIs related to knowledge continue to predominate (the knowledge covered in the official programme). The teacher constantly linked what needs to be studied and how to do it with the "content" of the programme. A programme that the teacher must address in its entirety, in the time and form agreed with the other mathematics teachers in the institution. All this added to the exam (called "deber común" [common assessment]) that, at the end of the unit of study, students must take individually and that will be reviewed and qualified by some other teacher. These institutional restrictions place the teacher in a situation whose action leads her to generate this type of OI. The same teacher, in another situation, would develop other OIs. Indeed, she participates in a group of professors that compose the research team on didactics of mathematics in a university. In that position, different from that of the school teacher, she questions the traditional exercises, having generated there an SRP proposal on the instantaneous velocity and the sign of the derivative for high school students. Both the changes that she made with the SRP on parabolic antennas and the SRP she created together with the study group of the university show that the teacher has the capacity and knowledge 
to manipulate and manage mathematical knowledge. But the situation of adjusting an SRP to a study programme led her to use this set of OIs that eventually produced an instrument that had nothing to do with a genuine SRP. In other words, the instrumentalization process eventually produced an instrument that is far removed from the original SRP artefact. This happens because the SRP cannot adapt to the programmes due to the nature of this artefact and the necessary stances to carry it forward in a real classroom. Programmes should, conversely, be formulated on the basis of the SRPs.

There are less OIs related to the time and the teacher. The former alludes to the control that the teacher must have throughout the study process, while the latter alludes to the teacher's actions to cover the contents of the programme within the agreed deadlines and in the least complex form for the students. Together with all of the above, this led the teacher to use OIs from "classical" teaching. In other words, a type of teaching where mathematics is studied in a segmented way, by units and topics that follow a previously established official programme.

Detailing the characteristics and gestures of an SRP, this type of SRP causes the starting question of the SRP to lose its generativity and its arborescent power, since the generation of derived questions is cancelled. The tasks become guides of actions to be developed, and thus, possible gestures compatible with, for example, asking questions (the students) and seeking answers (the students themselves) are cancelled. By not generating derived questions, the research component is inhibited as an initial stage in the construction of answers, and it is prevented from deciding on what students' knowledge is or is not useful, blocking gestures that are typical of studying and researching. Nor are the stances related to "tracking," identifying, and delimiting the possible courses enhanced, let alone the specifics within them that could contribute to the response, as in what way and with what knowledge the tasks must be solved are determined in advance. It means that the decisions made do not create the conditions for the development of gestures that are typical of exploring disciplines and delimiting areas. The SRP develops linearly, so the inputs and outputs of the topics do not happen. Furthermore, it is not necessary to clarify, to deepen, the knowledge that would help solve the task since, as said before, they are determined in advance. This leads to that there is nothing to adjust on the so-called right shade of grey. About the medium of study, we could consider that there are resources that have been incorporated, such as the internet searches that the students had to develop, which, although carried out outside the classroom, were specified by the groups. However, they 
were not considered because they made you "waste your time." In this way, a medium was incorporated that never became part of the medium of study.

The teacher is the one who determines each step of the tasks, from the actions to the times (in minutes) the students have to solve them. This is far from conducive to cooperative and collaborative study gestures and/or research work. It is also not possible to generate instances in which each member or study group should have disseminated the answer. In this way, no moments of questioning, acceptance, and resistance were generated other than those led by the teacher. Therefore, we conclude that the teacher's OIs in this situation promote gestures that are contrary to those required to the proper use of the SRP available in the book.

Now, if these types of OI do not favour an activity compatible with the stances necessary in the management of an SRP, then, what type of OIs would be necessary to do so?

\section{CONCLUSIONS}

The OIs are not absolute. The situation, the institution, the ghost of the common duty, etc. are combined so that this teacher, who is excellently gifted in her mathematical knowledge, has no escape and assimilates the resource from a scheme of classical teaching, of strong control, where only a few didactic gestures survive. From our viewpoint, in another situation, or, in that situation, but without the institutional restrictions, she could have acted differently. We do not know what weighs more, whether a long experience in a traditional context conditioned by all that has been described or a total change in rules of the game, which would enable the didactic gestures that the life of the SRP needs. In any case, we are optimistic about this last hypothesis, as long as the mathematical mastery -that it is evident that the teacher has- is preserved as a necessary condition to transform knowledge, raise questions about it, etc., because it is clear that she transformed what she had in her hands, even if not in the expected sense.

\section{AUTHORSHIP CONTRIBUTION STATEMENTS}

VP carried out the fieldwork on the implementation of the SRP, its description, and the analysis of the data. MRO is responsible for the overall guidance of the work and the aspects related to the TCF, its links with the instrumental approach, and the identification of the OIs. Both authors carried 
out the methodology, generation of categories of analysis, the theoretical framework that guides the methodological decisions, and the general organisation of the text.

\section{DATA AVAILABILITY STATEMENT}

The data supporting the results of this study will be provided by the corresponding author, $[\mathrm{VP}]$, upon reasonable request.

\section{REFERENCES}

Bellenoué, F., Chevalarias, N., Chauvin, P., Dherissard, S., Ducos, C., Gaud, D., \& Minet, N. (2014). Enseigner les mathématiques en lère $S$ : Trois parcours sur l'analyse et la géométrie analytique. IREM de Poitiers.

Bueno-Ravel, L., \& Gueudet, G. (2013). L'approche instrumentale des genèses d'usage : le cas des bases d'exercices en ligne. Des technologies aux ressources numériques, genèses d'usages et genèses documentaires. In : Les technologies numériques pour l'enseignement - Usage, dispositif et genèses (pp. 106-124). Octarès.

Chevallard, Y. (2004). Vers une didactique de la codisciplinarité. Notes sur une nouvelle épistémologie scolaire. $13 \mathrm{p}$.

http://yves.chevallard.free.fr/

Gueudet, G., \& Trouche L. (2008). Du travail documentaire des enseignants : genèses, collectifs, communautés. Le cas des mathématiques. Education et didactique, 2(3), 7-33.

Gueudet, G., Lebaud, M-P., Otero, M. R., \& Parra, V. (2018). Travail documentaire des professeurs et parcours d'étude et de recherche : une étude de cas en première S. Recherches en Didactiques des Mathématiques, 38(3), 275-314.

Otero, M. R. (2019). Competencias ¿Para qué? Unicen.

Parra, V., \& Otero, M. R. (2018). Antecedentes de los Recorridos de Estudio e Investigación (REI): características y génesis. Revista electrónica de investigación en educación en ciencias. 13(2), 1-18. 
Rabardel, P. (1995). Les hommes et les technologies: Approche cognitive des instruments contemporains. Armand Colin.

Rabardel, P. (2002). People and technology: a cognitive approach to contemporary instruments. Université Paris 8.

Trouche, L. (2016). Prendre en compte les métamorphoses du Numérique : vers une approche documentaire du didactique. Revista Union 45, 7 23.

Trouche, L., Gueudet, G., Pepin, B, \& Aldon, G. (2020). L'approche documentaire du didactique. 13 p. https://hal.archives-ouvertes.fr/hal$\underline{02512596 / \text { document }}$

Vygotsky, L. S. (1978). Mind in society: The development of higher psychological processes. Harvard University Press.

Vergnaud, G. (1990). La théorie des champs conceptuels. Recherches en Didactique des Mathématiques, 10(23), 133-170.

Vergnaud, G. (1998). A comprehensive theory of representation for mathematics education. Journal of Mathematical Behavior, 17(2), 167-181.

Vergnaud, G. (2007). Forma operatoria y forma predicativa del conocimiento. In: Actas Primer Encuentro Nacional sobre Enseñanza de la Matemática (pp. 1-25). Tandil, Argentina.

Vergnaud, G. (2013). Pourquoi la théorie des champs conceptuels ? Infancia y aprendizaje, 36(2), 131-161.

\section{Annex I}

\begin{tabular}{|c|c|c|c|c|}
\hline \multirow{2}{*}{ OI } & \multicolumn{2}{|c|}{ Interview 1} & \multicolumn{2}{|c|}{ Interview 2} \\
\hline & Time & Line(s) & Time & Line(s) \\
\hline $\begin{array}{l}\text { It is necessary to give meaning to } \\
\text { what is taught. }\end{array}$ & 02’13 & $11-14$ & $\begin{array}{l}277^{\prime} 40 \\
27 ' 54 \\
29 ' 27\end{array}$ & $\begin{array}{l}266-268 \\
268-271 \\
285-287\end{array}$ \\
\hline $\begin{array}{l}\text { The topics of the programme must be } \\
\text { addressed. } \\
\text { The SRP allows the contents of the }\end{array}$ & $02 ’ 57$ & $17-20$ & $\begin{array}{l}06^{\prime} 14 \\
08^{\prime} 32\end{array}$ & $\begin{array}{l}55-57 \\
74-76\end{array}$ \\
\hline
\end{tabular}
programme to be processed. 
It is necessary to prepare the students' encounter with the programme content.

It is necessary to control time.

Splitting the class into two groups allows you to control time.

$\begin{array}{llll}03 ' 17 & 20-27 & 01 ' 27 & 8-18 \\ 06 ' 08 & 52-53\end{array}$

It is necessary that students carry out the investigations outside the classroom not to waste time.

The students do not know how to investigate, the teacher must help them.

Framed personal works (FPWs) provide research methods to the students.

The students want to do what the teacher indicates.

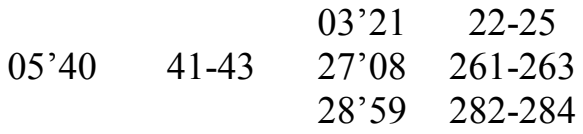

It is necessary to involve and motivate students.

The teacher must mark the topic at $06^{\prime} 26 \quad 47-51 \quad 04^{\prime} 40 \quad 40-41$ the beginning of the SRP.

It is necessary to involve and motivate students.

GeoGebra motivates students.

Verifying GeoGebra outputs from the algebraic view with the calculations is a motivation for the students.

The SRP motivates students.

05’59 44-47 04’47 46-49

It is necessary to talk about orthogonality before going through the scalar product.

Treating orthogonality linked only to the scalar product is very theoretical 07’46 58-61 11'44 109-112 and not very useful.

Perpendicularity is an instrument. 
Orthogonality can be treated as

perpendicularity.

It is necessary to make up for lost

time because of the SRP.

$10^{\prime} 24 \quad 81-86 \quad 40 ’ 00 \quad 400-404$

It is necessary to control time.

It is necessary for the teacher to give all the tools to the students so that

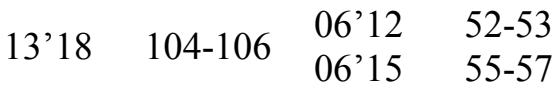

they can calculate.

The students are not in a position to calculate alone.

GeoGebra reduces students'

difficulties because it contains a tool to determine the tangent line.

The teacher must help students find good ideas.

17’'42 138-141 39'10 398-399

It is necessary to control time.

It is necessary that students find

good ideas before ten minutes.

$14^{\prime} 09 \quad 115-121 \quad 14^{\prime} 55 \quad 137-141$

The teacher cannot lose control of

the class times.

GeoGebra is very intuitive for

students.

Students do not find it difficult to use $\quad 18^{\prime} 02 \quad 146-151 \quad 066^{\prime} 33 \quad 58-60$

GeoGebra because they have seen

the teacher use it.

The teacher should ask students to

formulate questions.

The teacher should not put students at stake.

The teacher must avoid situations

$19 ’ 52 \quad 162-164 \quad 12 ’ 34 \quad 115-122$

that students cannot solve.

It is necessary to manage resources

well to help the students.

$20^{\prime} 17 \quad 164-168 \quad 37^{\prime} 07 \quad 389-391$

It is necessary to propose to the students exercises very similar to those proposed in class.

$17^{\prime} 41 \quad 141-144 \quad 01^{\prime} 18 \quad 8-10$

21’31 175-179 21’00 198-199 
It is necessary to propose

hyperclassical activities to students.

The SRP allows the contents of the

programme to be processed.

The SRP allows students to review

21'59 179-191 23'13 217-221

the subjects they have studied in

previous years.

The SRP motivates students.

SRPs allow students to tell a story

behind the content.

The narrative that is behind the

23’31 194-197 29'57 292-295 problems proposed in an SRP makes

students feel that they are more friendly.

The SRP allow students to show

what mathematics is for.

23’58 $199 \quad 03^{\prime} 17 \quad 21-22$

The SRP motivates students.

The final exam must contain both $\quad 25^{\prime} 50 \quad 213-214 \quad 29^{\prime} 00 \quad 286-288$ contextualised and technical tasks. 